\title{
STRESS DAN KEPRIBADIAN MAHASISWA PTKIN MENGHADAPI COVID-19
}

\author{
Ari Pamungkas \\ Institut Agama Islam Negeri Palangkaraya, Kalimantan Tengah \\ pamungkasary23@gmail.com
}

\begin{abstract}
The Covid-19 pandemic has had a significant impact on various dimensions of life including increasing stress among students. Therefore, this study aims to analyze the relationship between stress levels and personality types of state Islamic religious college students (PTKIN). This research is a type of quantitative research. The sample in this study were 100 students of the Faculty of Ushuluddin Adab and Da'wah at IAIN Palangkaraya using purposive random sampling technique. The data in this study used 2 standardized instruments, namely the Eysenck Personality Inventory (EPI) instrument to measure extrovert-introvert personality and stress levels using the DASS-21 instrument. The conclusion of the research data analysis is that students who have a stress level during the Covid-19 pandemic are dominated by students who have an introverted personality type. This situation shows that introvert personality types are at greater risk of experiencing stress in the face of the Covid-19 pandemic compared to students with extrovert personality types.
\end{abstract}

\section{Keywords: Covid-19; Stress; Students; Introverts; Extroverts}




\section{A. Pendahuluan}

Covid-19 telah menjadi pandemi global yang menjangkit ribuan orang di dunia. Hampir sebagian besar masyarakat dunia berada dalam ketidakpastian dan menerima banyak informasi melalui berbagai macam media. Kondisi ini tanpa disadari mengakibatkan kepanikan dan stres. Tidak heran jika masyarakat banyak menemui kendala dalam kehidupan sehari-harinya. Oleh karena itu, dalam kondisi pandemi tersebut perlu manajemen yang baik tidak hanya pengelolaan krisis namun juga pengelolaan informasi agar dapat meminimalisir stres akibat informasi tidak benar. ${ }^{1}$

Physical distancing dan isolasi diri di rumah terus digaungkan demi memutus mata rantai penularan virus Corona. Namun, di sisi lain, menjaga jarak dalam waktu yang lama dapat menimbulkan tekanan psikologis tersendiri. Dalam konteks ini, pandemi Covid-19 telah berdampak terhadap kesehatan mental masyarakat. Khusunya mahasiswa yang menjalani aktivitas belajar di rumah. Stres berat di tengah pandemi bukan masalah sepele. Sebab, stres dapat mempengaruhi bagaimana mereka menyesuaikan diri. Masalah kesehatan mental ini biasanya akan memengaruhi seseorang dalam bersikap, berpikir, serta bisa memicu berbagai masalah fisik maupun emosional.

Stres merupakan perasaan wajar yang sering dialami setiap orang dalam kondisi tertentu. Perasaan stres dapat terjadi kapan saja ketika kondisi seseorang merasa tertekan oleh suatu situasi atau kondisi. Oleh karenanya, stres sudah menjadi bagian dari kehidupan seseorang untuk mencapai kehidupan yang lebih baik. Salah satunya yaitu terjadi pada mahasiswa.

Stresor pada mahasiswa dalam dunia pendidika dibagi menjadi tuntutan eksternal dan tuntutan internal. Tuntutan eksternal dapat bersumber dari tugas- tugas kuliah, beban pelajaran, tuntutan orang tua untuk berhasil dalam kuliah dan penyesuaian sosial di lingkungan kampus. Tuntutan internal

${ }^{1}$ Mualimin, "Manajemen Dakwah Melalui Bantuan Kemanusiaan Korban Banjir Di Kabupaten Sambas," Ilmu Dakwah: Academic Journal for Homiletic Studies 11, no. 1 (30 Juni 2017): 112, https://doi.org/10.15575/idajhs.v11i1.1104. 
berasal dari harapan mahasiswa untuk dapat mengikuti pelajaran dengan baik.

Tingkat stres yang dialami oleh mahasiswa baru dapat berbeda-beda. Salah satu faktor yang menentukan tingkat stres adalah mekanisme penanganan masalah atau coping mechanism yang sangat ditentukan oleh kepribadian individual. ${ }^{2}$ Friedman juga mengemukakan pendapat yang sama, yakni bahwa kepribadian merupakan sebuah aspek penting yang menentukan kondisi kesehatan dan psikologis. ${ }^{3}$ Stres yang dialami oleh setiap manusia dapat disebabkan dari berbagai banyak faktor-faktor yang memicunya seperti diantaranya masalah ekonomi, masalah pekerjaan atau tugas, masalah hubungan sosial, masalah kesehatan, dan masih banyak lagi. Selain itu stres juga tidak memandang jenis kelamin, usia (baik itu tua, dewasa, remaja, bahkan anak-anak sekalipun) maupun status sosial atau jabatan seperti seorang boss, staff, manajer, direktur, dokter, guru, mahasiswa.

Mahasiswa pada keadaan physical distancing mengalami perubahan dalam kegiatan perkuliahan. Sebelum terjadinya physical distancing mereka biasa berkuliah tatap muka langsung dengan dosen, pergi ke kampus, bertemu dengan banyak orang, melakukan kegiatan-kegiatan di lokasi kampus atau pun pergi jalan bareng teman-teman seusai kuliah. Tidak bertemu langsung dengan teman saja membuat mereka perlu penyesuaian karena mereka harus melakukan kontak social via telepon atau jaringan internet seperti social media. Perkuliahan yang mereka lakukan juga terjadi perubahan metode belajar. Biasa tatap muka dengan dosen langsung, namun sekarang mereka harus kuliah dengan metode daring. Penyesuaian itu saja membuat mereka membuutukan waktu untuk proses penyesuaian, ditambah dukungan internet yang tidak stabil. Berubahnya metode tentu akan berpengaruh pada bagaimana mahasiswa menyesuaikan diri dengan kuliah daring, dimana kuliah ini merupakan hal baru yang mereka temui. Kondisi ini secara tidak langsung sangat memungkinkan menjadi pemicu munculnya stress. 2011).

${ }^{2}$ A.E Nurdin, Tumbuh Kembang Perilaku Manusia (Jakarta: EGC,

${ }^{3}$ H.S Friedman, Kepribadian Teori Klasik dan Riset Modern (Jakarta: Erlangga, 2006). 
Stres mahasiswa dalam perkuliahan daring ini dapat terjadi disebabkan mahasiswa merasakan adanya sebuah tekanan baik dari internal (dalam diri) ataupun dari eksternal (luar diri). Adapun tekanan eksternal (dari luar) yang mampu mempengaruhi tingkat stres mahasiswa dalam perkuliahan daring diantaranya adanya tuntutan dari berbagai pihak agar focus mengikuti kuliah daring ini, beban tugas yang tinggi, kerumitan tugas, adanya batasan waktu dalam mengumpulkan tugas yang telah ditentukan oleh dosen, fasilitas seperti kuota terbatas, dan lain-lain. Sedangkan tekanan dari dalam dapat berupa kurangnya tingkat motivasis mahasiswa dalam perkuliahan daring, kurangnya memahmi metode perkuliahan yang diberikan, ketidakmampuan mahasiswa dalam menyesuaikan diri, pengaruh tipe kepribadian, dan lain-lain.

Friedman juga mengemukakan pendapat yang sama, yakni bahwa kepribadian merupakan sebuah aspek penting yang menentukan kondisi kesehatan dan psikologis. ${ }^{4}$ Menurut Wade dan Tavris, kepribadian (personality) adalah pola perilaku, tata krama, pemikiran, motif, dan emosi yang khas yang memberikan karakter kepada individu sepanjang waktu dan pada berbagai situasi yang berbeda. Pola tersebut meliputi banyak ciri kepribadian, yaitu cara-cara dan kebiasaan berperilaku, berpikir, dan merasakan, pemalu, ramah, mudah berteman, kasar, murung, dan percaya diri. ${ }^{5}$

Allport berpendapat bahwa kepribadian merupakan karakter, dan karakter merupakan kepribadian. Sedangkan arti kata kepribadiana adalah keseluruhan cara seorang individu bereaksi dan berinteraksi dengan individu lain. ${ }^{6}$ Jung berpendapat bahwa kepribadian dibagi menjadi dua, yaitu ekstrovert dan introvert. Kepribadian ekstrovert yaitu individu yang mempunyai ciri-ciri tidak suka belajar sendiri, suka mengambil tantangan, tidak banyak pertimbangan (easy going) dan memerlukan umpan balik dari guru pada saat proses pembelajaran. Sedangkan kepribadian introvert adalah individu

\footnotetext{
${ }^{4}$ Friedman.

5 Carole Wade dan Carol Tavris, Psikologi (Jakarta: Erlangga, 2008).

${ }^{6}$ Inge Hutagalung, Pengembangan Kepribadian (Jakarta: PT. Indeks, 2007).
} 
yang mempunyai ciri-ciri suka belajar sendiri, berhati-hati dalam mengambil keputusan, tenang dan rajin. ${ }^{7}$

Berdasarkan uraian tersebut, maka pemahaman pola kepribadian pada mahasiswa Perguruan Tinggi Keagamaan Islam Negeri (PTKIN) dalam perkuliahan daring menjadi penting guna mengantisipasi timbulnya stres serta menemukan upaya penanganan terhadap stres yang sesuai dengan tipe kepribadian, berupa preventif ataupun setelah kejadian stres. Kajian ini merupakan penelitian lapangan. Metode yang digunakan dalam penelitian ini adalah kuantitatif deskriptif. sampel penelitian ini adalah 100 mahasiswa Fakultas Ushuluddin Adab dan Dakwah IAIN Palangkaraya dengan menggunakan teknik Purposive Random Sampling. Data pada penelitian ini menggunakan 2 instrumen yang telah dibakukan, yaitu instrumen Eysenck Personality Inventory (EPI) untuk mengukur kepribadian ekstrovert-introvert dan tingkat stress menggunakan instrument DASS-21

\section{B. Tingkat Stres Mahasiswa Mengalami Covid-19}

Covid-19 tidak hanya memberikan dampak pada kesehatan fisik, namun juga terhadap kesehatan mental. Berbagai penelitian terbaru menunjukkan bahwa pandemi Covid-19 memberikan efek terhadap berbagai dimensi kejiwaan manusia seperti kecemasan dan stres. ${ }^{8}$ Kondisi tersebut juga terjadi pada

${ }^{7}$ Arini Safitri, "Pemetaan Beban Kerja dan Perancangan Kerja di Departemen Kredit Pada PT. Bank X Pusat Surabaya" (masters, UNKNOWN, 2015), http://digilib.ubaya.ac.id/pustaka.php/240515; Arini Safitri, A. J. Tjahjoanggoro, dan V. Heru Hariyanto, “Pemetaan Beban Kerja Dan Perancangan Kerja Di Departemen Kredit Pada PT. Bank X Pusat," CALYPTRA 5, no. 1 (2016): 1-20.

${ }^{8}$ Lihat Muhammad Iqbal dan Lutfiyah Rizqulloh, "Deteksi Dini Kesehatan Mental Akibat Pandemi Covid-19 Pada Unnes Sex Care Community Melalui Metode Self Reporting Questionnaire," PRAXIS 3, no. 1 (29 September 2020): 20-24, https://doi.org/10.24167/praxis.v3i1.2730; Berta Rodrigues Maia dan Paulo César Dias, "Anxiety, Depression and Stress in University Students: The Impact of COVID-19," Estudos de Psicologia (Campinas) 37 (2020), https://doi.org/10.1590/1982-0275202037e200067; Wahyu Setyaningrum dan Heylen Amildha Yanuarita, "Pengaruh Covid-19 Terhadap Kesehatan Mental Masyarakat Di Kota Malang," JISIP (Jurnal 
mahasiswa Fakultas Ushuluddin Adab dan Dakwah IAIN Palangkaraya. Hal itu sebagaimana hasil sampling diperoleh terhadap mahasiswa Fakultas Ushuluddin Adab dan Dakwah IAIN Palangkaraya. Data yang diperoleh menunjukkan bahwa tingkat stres mahasiswa dapat dibagi menjadi lima klasifikasi. Secara spesifik tingkat stres mahasiswa berdasarkan lima klasifikasi tersebut adalah sebagaimana dalam tabel berikut :

Tabel 1

Tingkat Stres Mahasiswa $(\mathbf{n}=100)$

\begin{tabular}{|l|c|}
\hline \multicolumn{1}{|c|}{ Tingkat Stres } & Jumlah \\
\hline Stres Normal & 32 \\
\hline Stres Ringan & 7 \\
\hline Stres Sedang & 36 \\
\hline Stres Berat & 17 \\
\hline Stres Sangat Berat & 8 \\
\hline \multicolumn{1}{|c|}{ Total } & $\mathbf{1 0 0}$ \\
\hline
\end{tabular}

Data tersebut menunjukkan bahwa tingkat stres yang dialami oleh mahasiswa di Fakultas Ushuluddin Adab dan Dakwah IAIN Palangkaraya sangat beragam. Hanya saja kondisi stres dengan tingkat normal dan sedang sangat mendominasi. Data tersebut juga menunjukkan bahwa secara mayoritas, mahasiswa di fakultas Ushuluddin Adab dan Dakwah IAIN Palangkaraya tidak mengalami tingkat stres berat. Kondisi ini tentu berbeda dengan tingkat stres di daerah dan lingkungan yang berbeda. ${ }^{9}$

Ilmu Sosial Dan Pendidikan) 4, no. 4 (30 November 2020), https://doi.org/10.36312/jisip.v4i4.1580; Deshinta Vibriyanti, "Kesehatan Mental Masyarakat: Mengelola Kecemasan di Tengah Pandemi Covid-19," Jurnal Kependudukan Indonesia 0, no. 0 (28 Juli 2020): 69-74, https:/ / doi.org/10.14203/jki.v0i0.550.

${ }^{9}$ Lihat Moh Muslim, "Manajemen Stress pada Masa Pandemi Covid-19," ESENSI: Jurnal Manajemen Bisnis 23, no. 2 (28 Agustus 2020): 194-95; Livana Ph, Mohammad Fatkhul Mubin, dan Yazid Basthomi, “'Learning Task' Attributable to Students' Stress During the Pandemic Covid-19," Jurnal Ilmu Keperawatan Jiwa 3, no. 2 (20 Juni 2020): 203, https://doi.org/10.32584/jikj.v3i2.590; Bela Novita Amaris Susanto, "Literatur Review: Dampak Gangguan Kesehatan Mental Pada Petugas Kesehatan Selama Pandemi Coronavirus Disease 2019," Medica 
Temuan tentang perbedaan tingkat stres mahasiswa terhadap Covid-19 merupakan sesuatu yanh wajar. Respon seseorang terhadap stres bergantung pada jenis stresornya, kapan waktunya, bagaimana sifat orang yang mengalami stres dan bagaimana orang yang mengalami stres bereaksi terhadap stresornya. ${ }^{10}$ Sejalan dengan itu dalam pandangan Rofam, pengalaman kehidupan berkontribusi terhadap kondisi kejiwaan termasuk didalamnya tingkat stres. ${ }^{11}$ Dampak negatif dari stres terhadap mahasiswa dapat berupa penurunan konsentrasi dan pemusatan perhatian selama kuliah, penurunan minat, demotivasi diri bahkan dapat menimbulkan perilaku kurang baik. 12 Sejalan dengan pendapat tersebut Sumarni dan Handayani memandang bahwa permasalahan kejiwaan dapat menimbulkan produktivitas manusia dalam jangka panjang. Begitu juga sebaliknya kondisi kejiwaan yang sehat akan berimplikasi pada kebahagiaan hidup manusia. ${ }^{13}$

Hasil penelitian Maia dan Diaz menunjukkan bahwa para siswa yang dievaluasi selama periode pandemi menunjukkan tingkat kecemasan, depresi, dan stres yang jauh lebih tinggi,

Hospitalia: Journal of Clinical Medicine 7, no. 1A (28 Agustus 2020): 26170, https://doi.org/10.36408/mhjcm.v7i1A.462.

${ }^{10}$ Nasib Tua Lumban Gaol, "Teori Stres: Stimulus, Respons, Dan Transaksional," Buletin Psikologi 24, no. 1 (1 Juni 2016): 1-11, https://doi.org/10.22146/bpsi.11224.

11 Galuh Nashrulloh Kartika Majangsari Rofam, "Perspektif Bimbingan Konseling dalam Pendidikan Islam," NALAR: Jurnal Peradaban dan Pemikiran Islam 1, no. 2 (2017): 95, https:// doi.org/10.23971/njppi.v1i2.906.

${ }^{12}$ Hamza Mohammad Abdulghani, "Stres and depression among medical students: a cross sectional study at Medical College in Saudi Arabia," Pakistas Journal of Medical Science 24, no. 1 (2008).

13 Sumarni Sumarni, "Proses Penyembuhan Gejala Kejiwaan Berbasis Islamic Intervention Of Psychology," NALAR: Jurnal Peradaban dan Pemikiran Islam 3, no. 2 (2019): 135, https://doi.org/10.23971/njppi.v3i2.1677; Iin Handayani, “Konsep Bimbingan dan Konseling Pribadi-Sosial dalam Pengembangan Positive Mental Attitude Generasi Z," NALAR: Jurnal Peradaban dan Pemikiran Islam 3, no. 1 (30 Juni 2019): 51, https://doi.org/10.23971/njppi.v3i1.1283. 
dibandingkan dengan para siswa pada masa-masa normal. ${ }^{14}$ Hasil tersebut menunjukkan bahwa pandemi memiliki efek psikologis negatif bagi dunia pendidikan khususnya peserta didik. Dalam konteks tersebut, Davidson menyebutkan bahwa sumber stres akademik dapat meliputi situasi yang monoton, kebisingan, tugas yang terlalu banyak, harapan yang mengadangada, ketidakjelasan, kurang adanya kontrol, keadaan bahaya dan kritis, tidak dihargai, diacuhkan, kehilangan kesempatan, aturan yang membingungkan, tuntutan yang saling bertentangan, dan deadline tugas perkuliahan. ${ }^{15}$

\section{Hubungan Kepribadian Mahasiswa dengan Tingkat Stres Menghadapi Covid-19}

Tingkat stres mahasiswa dalam menghadapi Covid-19 sangat dipengaruhi oleh tipe kepribadian mahasiswa tersebut. Dalam penelitiannya Zulkarnaen menemukan bahwa stres akan muncul jika terdapat tuntutan dan tekanan yang melebihi kemampuan adaptasi seseorang. Pada kondisi ini seluruh tipe kepribadian dapat berpengaruh terhadap tingkat stres seseorang. ${ }^{16}$ Temuan tersebut sejalan dengan hasil penelitian Baktiyar, Hasanah, dan Nursetiawati bahwa dalam konteks kepribadian, manusia dapat dibagi menjadi introvert dan ekstrovert. Selain dipengaruhi tipe kepribadian, kemampuan manajemen stres antara kedua kepribadian tersebut sangat menentukan tingkat stres yang dialami. ${ }^{17}$

14 Maia dan Dias, "Anxiety, Depression and Stress in University Students," 1 .

15 S Purwati, "Tingkat Stres Akademik Pada Mahasiswa Reguler Angkatan 2010 Fakultas Ilmu Keperawatan Universitas Indonesia" (Skripsi, Jakarta, Universitas Indonesia, 2012).

16 Wandy Zulkarnaen, "Pengaruh Tipe Kepribadian Terhadap Stress Karyawan Pada CV. Adi Jaya Nusantara," Jurnal Abdimas BSI: Jurnal Pengabdian Kepada Masyarakat 1, no. 3 (20 Agustus 2018): 533-34, https://doi.org/10.31294/jabdimas.v1i3.4115.

17 Kurnia Baktiyar, Uswatun Hasanah, dan Sitti Nursetiawati, "Perbedaan Manajemen Stres Pada Remaja Dengan Kepribadian Introvert Dan Ekstrovert Di SMAN 68 Jakarta," JKKP (Jurnal Kesejahteraan Keluarga Dan Pendidikan) 3, no. 1 (11 April 2016): 1, https://doi.org/10.21009/JKKP.031.01. 
Penelitian yang dilakukan terhadap mahasiswa Fakultas Ushuluddin Adab dan Dakwah IAIN Palangkaraya menunjukkan bahwa terdapat perbedaan yang cukup signifikan antara dua tipe kepribadian mahasiswa. Secara spesifik data tersebut sebagaimana dalam tabel berikut :

Tabel 2

Tipe Kepribadian Mahasiswa $(\mathrm{n}=100)$

\begin{tabular}{|c|c|}
\hline Tipe Kepribadian & Jumlah \\
\hline Introvert & 75 \\
\hline Ekstrovert & 25 \\
\hline Total & 100 \\
\hline
\end{tabular}

Tabel tersebut menunjukkan bahwa sebagian besar mahasiswa Fakultas Ushuluddin Adab dan Dakwah memiliki tipe kepribadian introvert yaitu 75 mahasiswa (75\%) lebih banyak dibanding tipe kepribadian ekstrovert sebesar 25\%. Penelitian ini juga menemukan bahwa di antara dua tipe kepribadian tersebut, mahasiswa yang memiliki kepribadian introvert lebih dominan mengalami stres ringan hingga sangat berat. Jumlah mahasiswa dengan kepribadian introvert yang mengalami tingkat stres sedang hingga sangat berat adalah sebanyak 60 orang $(60 \%)$. Sedangkan jumlah mahasiswa dengan kepribadian ekstrovert yang mengalami tingkat stres sedang hingga sangat berat adalah sebanyak 8 orang $(8 \%)$. Secara spesifik temuan penelitian terkait hubungan kepribadian dengan tingkat stres sebagaimana data berikut :

Tabel 3

Tipe Kepribadian introvert

\begin{tabular}{|c|c|}
\hline Tingkat Stres & Jumlah \\
\hline Stres Normal & 15 \\
\hline Stres Ringan & 7 \\
\hline Stres Sedang & 31 \\
\hline Stres Berat & 15 \\
\hline Stres Sangat Berat & 7 \\
\hline Total & 75 \\
\hline
\end{tabular}


Tabel 4

Tipe Kepribadian Ekstrovert $(\mathrm{n}=100)$

\begin{tabular}{|l|c|}
\hline \multicolumn{1}{|c|}{ Tingkat Stres } & Jumlah \\
\hline Stres Normal & 17 \\
\hline Stres Ringan & 0 \\
\hline Stres Sedang & 5 \\
\hline Stres Berat & 2 \\
\hline Stres Sangat Berat & 1 \\
\hline \multicolumn{1}{|c|}{ Total } & $\mathbf{2 5}$ \\
\hline
\end{tabular}

Temuan tentang dominasi mahasiswa berkepribadian introvert yang mengalami stres sedang hingga sangat berat pada dasarnya mengkonfirmasi pandangan Jung. Dalam pandangannya sebagaimana dikutip Alwisol, Jung menyebutkan bahwa seseorang yang memiliki kepribadian introvert biasanya cenderung tertutup, menarik diri dari kontak sosial, tidak mudah percaya, sering terlalu banyak berpikir (overthinking) dan sedikit bertindak, sering dicap sebagai orang yang sombong dan berbahaya, sering terjebak di zona nyaman (pemalas), kesulitan memulai pembicaraan, merasa cepat lelah jika dihadapkan dengan keramaian (sosialisasi), kesulitan menerima suasana baru (sulit menerima perubahan), banyak yang egois, sulit dimengerti, mudah mendendam dan memiliki amarah yang besar, banyak yang terkena penyakit phobia dan penyakit mental, diam-diam menghanyutkan, banyak yang cuek dengan penampilan, suka berdiam diri di kamar dan bicaranya pedas. Sedangkan kepribadian orang ekstrovert identik dengan berhati besar, interaksi sosial yang baik, terbuka, bersemangat, hangat, dan empati. 18

Pandangan Jung diperkuat dengan hasil penelitian Hidayah, Basuki, dan Fitriah bahwa kepribadian introvert lebih beresiko mengalami depresi karena memiliki rasa kurang percaya diri, dan lebih cenderung pesimis terhadap permasalahan. ${ }^{19}$ Begitu juga dengan hasil penelitian Erasmus dan

18 Alwisol, Psikologi kepribadian (Malang: UMM Press, 2014).

${ }^{19}$ Nurhidayah Nurhidayah, Ismu Basuki, dan Endik mufidatul Fitriah, "Hubungan Tipe Kepribadian Dengan Kejadian Depresi Pada Lansia Di UPT PSLU Jombang - Pare Kediri," Jurnal Ilmu Kesehatan 5, no. 1 (2016): 112, https://doi.org/10.32831/jik.v5i1.121. 
Nursyahrurahmah menunjukkan bahwa tingkat stres yang lebih tinggi dari rata-rata pada domain kehidupan tertentu dan cenderung lebih tinggi pada tipe kepribadian introvert dari pada tipe ekstrovert. ${ }^{20}$

\section{Kesimpulan}

Berdasarkan pembahasan di atas, dapat disimpulkan bahwa mahasiswa yang memiliki tingkat stres pada masa pandemic covid-19 dominan memiliki tipe kepribadian introvert. Keadaan ini menunjukkan tipe kepribadian introvert beresiko lebih besar mengalami stress dibandingkan dengan mahasiswa dengan tipe kepribadian ekstrovert. Layanan yang dapat diberikan kepada mahasiswa untuk menurunkan tingkat stres dalam masa pandemic covid-19 adalah layanan konseling individual maupun konseling kelompok. Diharapkan dilakukan screening terhadap kesehatan mental mahasiswa secara berkala untuk mengidentifikasi mahasiswa yang mengalami masalah psikologis seperti stres

\section{Daftar Pustaka}

Abdulghani, Hamza Mohammad. "Stres and depression among medical students: a cross sectional study at Medical College in Saudi Arabia." Pakistas Journal of Medical Science 24, no. 1 (2008).

Alwisol. Psikologi kepribadian. Malang: UMM Press, 2014.

Baktiyar, Kurnia, Uswatun Hasanah, dan Sitti Nursetiawati. "Perbedaan Manajemen Stres Pada Remaja Dengan Kepribadian Introvert Dan Ekstrovert Di SMAN 68 Jakarta." JKKP (Jurnal Kesejahteraan Keluarga Dan Pendidikan) 3, no. 1 (11 April 2016): 1-6.

https:// doi.org/10.21009/JKKP.031.01.

${ }^{20}$ Jolanie Erasmus, "The Relationship between Stress Levels and Personality Types among Adolescents Diagnosed with Acne Vulgaris" (Master Thesis, Potchefstroom, North-West University, 2005), https://repository.nwu.ac.za/handle/10394/19052; Nursyahrurahmah Nursyahrurahmah, "Hubungan antara Kepribadian Introvert dan Kelekatan Teman Sebaya dengan Kesepian Teman," Jurnal Ecopsy 4, no. 2 (27 September 2017): 113, https:/ / doi.org/10.20527/ ecopsy.v4i2.3852. 
Erasmus, Jolanie. "The Relationship between Stress Levels and Personality Types among Adolescents Diagnosed with Acne Vulgaris." Master Thesis, North-West University, 2005. https:// repository.nwu.ac.za/handle/10394/19052.

Friedman, H.S. Kepribadian Teori Klasik dan Riset Modern. Jakarta: Erlangga, 2006.

Gaol, Nasib Tua Lumban. "Teori Stres: Stimulus, Respons, Dan Transaksional." Buletin Psikologi 24, no. 1 (1 Juni 2016): 111-11. https://doi.org/10.22146/bpsi.11224.

Handayani, Iin. "Konsep Bimbingan dan Konseling PribadiSosial dalam Pengembangan Positive Mental Attitude Generasi Z." NALAR: Jurnal Peradaban dan Pemikiran Islam 3, no. 1 (30 Juni 2019): 51-63.

https:// doi.org/10.23971/njppi.v3i1.1283.

Hutagalung, Inge. Pengembangan Kepribadian. Jakarta: PT. Indeks, 2007.

Iqbal, Muhammad, dan Lutfiyah Rizqulloh. "Deteksi Dini Kesehatan Mental Akibat Pandemi Covid-19 Pada Unnes Sex Care Community Melalui Metode Self Reporting Questionnaire." PRAXIS 3, no. 1 (29 September 2020): 2024. https://doi.org/10.24167/ praxis.v3i1.2730.

Maia, Berta Rodrigues, dan Paulo César Dias. "Anxiety, Depression and Stress in University Students: The Impact of COVID-19." Estudos de Psicologia (Campinas) 37 (2020). https:// doi.org/10.1590/1982-0275202037e200067.

Mualimin. "Manajemen Dakwah Melalui Bantuan Kemanusiaan Korban Banjir Di Kabupaten Sambas." Ilmu Dakwah: Academic Journal for Homiletic Studies 11, no. 1 (30 Juni 2017): 111-32. https://doi.org/10.15575/idajhs.v11i1.1104.

Muslim, Moh. "Manajemen Stress pada Masa Pandemi Covid19." ESENSI: Jurnal Manajemen Bisnis 23, no. 2 (28 Agustus 2020): 192-201.

Nurdin, A.E. Tumbuh Kembang Perilaku Manusia. Jakarta: EGC, 2011. 
Nurhidayah, Nurhidayah, Ismu Basuki, dan Endik mufidatul Fitriah. "Hubungan Tipe Kepribadian Dengan Kejadian Depresi Pada Lansia Di UPT PSLU Jombang - Pare Kediri." Jurnal Ilmu Kesehatan 5, no. 1 (2016): 109-13. https:// doi.org/10.32831/jik.v5i1.121.

Nursyahrurahmah, Nursyahrurahmah. "Hubungan antara Kepribadian Introvert dan Kelekatan Teman Sebaya dengan Kesepian Teman." Jurnal Ecopsy 4, no. 2 (27 September 2017): 113-16.

https:// doi.org/10.20527/ecopsy.v4i2.3852.

Ph, Livana, Mohammad Fatkhul Mubin, dan Yazid Basthomi. “'Learning Task' Attributable to Students' Stress During the Pandemic Covid-19." Jurnal Ilmu Keperawatan Jiwa 3, no. 2 (20 Juni 2020): 203-8.

https:// doi.org/10.32584/jikj.v3i2.590.

Purwati, S. “Tingkat Stres Akademik Pada Mahasiswa Reguler Angkatan 2010 Fakultas Ilmu Keperawatan Universitas Indonesia." Skripsi, Universitas Indonesia, 2012.

Rofam, Galuh Nashrulloh Kartika Majangsari. "Perspektif Bimbingan Konseling dalam Pendidikan Islam." NALAR: Jurnal Peradaban dan Pemikiran Islam 1, no. 2 (2017): 95-109. https:// doi.org/10.23971/njppi.v1i2.906.

Safitri, Arini. "Pemetaan Beban Kerja dan Perancangan Kerja di Departemen Kredit Pada PT. Bank X Pusat Surabaya." Masters, UNKNOWN, 2015. http://digilib.ubaya.ac.id/pustaka.php/240515.

Safitri, Arini, A. J. Tjahjoanggoro, dan V. Heru Hariyanto. "Pemetaan Beban Kerja Dan Perancangan Kerja Di Departemen Kredit Pada PT. Bank X Pusat." CALYPTRA 5, no. 1 (2016): 1-20.

Setyaningrum, Wahyu, dan Heylen Amildha Yanuarita. "Pengaruh Covid-19 Terhadap Kesehatan Mental Masyarakat Di Kota Malang." JISIP (Jurnal Ilmu Sosial Dan Pendidikan) 4, no. 4 (30 November 2020). https:// doi.org/10.36312/jisip.v4i4.1580. 
Sumarni, Sumarni. "Proses Penyembuhan Gejala Kejiwaan Berbasis Islamic Intervention Of Psychology." NALAR: Jurnal Peradaban dan Pemikiran Islam 3, no. 2 (2019): 134-47. https:// doi.org/10.23971/njppi.v3i2.1677.

Susanto, Bela Novita Amaris. "Literatur Review: Dampak Gangguan Kesehatan Mental Pada Petugas Kesehatan Selama Pandemi Coronavirus Disease 2019." Medica Hospitalia: Journal of Clinical Medicine 7, no. 1A (28 Agustus 2020): 261-70. https:// doi.org/10.36408/mhjcm.v7i1A.462.

Vibriyanti, Deshinta. "Kesehatan Mental Masyarakat: Mengelola Kecemasan di Tengah Pandemi Covid-19." Jurnal Kependudukan Indonesia 0, no. 0 (28 Juli 2020): 69-74. https:// doi.org/10.14203/jki.v0i0.550.

Wade, Carole, dan Carol Tavris. Psikologi. Jakarta: Erlangga, 2008.

Zulkarnaen, Wandy. "Pengaruh Tipe Kepribadian Terhadap Stress Karyawan Pada CV. Adi Jaya Nusantara." Jurnal Abdimas BSI: Jurnal Pengabdian Kepada Masyarakat 1, no. 3 (20 Agustus 2018).

https:// doi.org/10.31294/jabdimas.v1i3.4115. 